\title{
THE ENABLEMENT OF CUSTOMER'S PARTICIPATION IN THE OPEN INNOVATION PROCESSES: AN ANALYTICAL FRAMEWORK
}

\author{
Aiste Vaisnore ${ }^{1}$, Monika Petraite ${ }^{2}$ \\ ${ }^{1}$ Kaunas University of Technology, Lithuania, a.gasiunaite@stud.ktu.lt \\ ${ }^{2}$ Kaunas University of Technology, Lithuania, monika.petraite@ktu.lt \\ cross $^{\text {ref }}$ http://dx.doi.org/10.5755/j01.em.17.4.3035
}

\begin{abstract}
The paper aims to provide an analytical framework for the enablement of customer participation in the open innovation process. Paper provides the definition of customer enablement to participate in open innovation process; suggests the more structured approach for the disclosure of important preconditions for the enablement of customer participation, and proposes the analytical framework for the enablement of customers' participation in the open innovation process, with reference to the industrial preconditions; strategic preconditions; firms' innovation capacities; and integrative capacities. Proposed analytical framework serves for deeper understanding on how firm facilitates the customer involvement and participation in OI process by creating the certain environment, conditions for enablement and what internal and external preconditions are inducing the customer enablement to participate in OI process.

Keywords: open innovation, customer involvement into innovation, customer participation, customer participation enablement, open innovation with customers.

JEL Classification: O32, L21, M19.
\end{abstract}

\section{Introduction}

The discussion on openness of innovation (Chesbrough, 2003; Gassmann, Enkel 2004; Chesbrough Vanhaverbeke, West, 2006) has led to the particular attention on the firm capabilities to identify, attract and anchor the external knowledge for innovation from different knowledge sources (Cohen and Levinthal, 1990; Flatten, Engelen, Zahra and Brettel, 2011; Kaarela, 2010; Zahra and George, 2002, Spithoven, Clarysse and Knockaert, 2010) and the extension of organizational boundaries in order to create value for customer (Chesbrough and Schwartz, 2007; Chesbrough, 2007). The new approach to open innovation by highlighting customer involvement perspective has attracted great interest of researchers and practitioners. Studies demonstrated increasingly active role of customers in innovation processes of the firm (Gales and Mansourcole, 1995; Piller, Ihl and Steiner, 2010; Salter and Laursen, 2006; Steiner, Tarman, Ihl and Piller, 2009; von Hippel, 1990). It was also proven that the identification of lead users and use of their knowledge inputs has positive effect on innovation performance (Piller et al., 2010; Piller and Ihl, 2009, Steiner et al., 2009; von Hippel, 1990). Interaction with customers can provide missing external inputs into the learning process of the firm (Van De Vrande, De Jong, Vanhaverbeke, De Rochemont, 2009). The role of customers as co-creators and creativity drivers was analysed and defined as a central entity in the value chain (Prahalad, 2004; von Hippel, 1990). Attention was drawn to the frequency and scope of customer-firm interaction influence to the performance (Gales and Mansour-Cole, 1995; Steiner et al., 2009) and also to the mode and kind of communication and interaction with customers in the context of innovation (Piller and Ihl, 2009).

Despite the substantial attention paid to the role of customers and users in the innovation process, little effort has been devoted to the understanding on how to enable customers' participation in the open innovation process. Von Hippel (1978), Herstatt and Von Hippel (1992), Thomke and von Hippel (2002), Reichwald and Piller (2003), Herstatt and Lettl (2004), Rohracher (2005), Von Hippel (2007), Lettl, Herstatt, Gemuenden (2006), Lettl (2007), O'Hern and Rindfleisch (2008), Piller and Ihl (2009), Belkahla and Triki (2011) in the scientific literature in general mention the circumstances for the customer(user)-firm interaction in order to develop innovation. However it does not discuss the customer enablement to participate in open innovation process settings in systematic (analytical??) way. The search for answers remains limited before we: 1) define the enablement customers' participation in open innovation process; 2) disclose the preconditions for the enablement of customers' participation; 3) construct/build the framework?? for analysis of the enablement of customers' participation in open innovation process. The paper focuses on these research questions, and aims to provide the analytical framework for the enablement of customer participation in the open innovation process. The paper is based on the comparative literature review and synthesis, as a method best suited for the theoretical agglomeration of already existing case studies and various research findings in the field. 
The paper provides the definition of customer enablement to participate in open innovation process; suggests the more structured approach for the disclosure of important preconditions for the enablement of customer participation, and proposes the analytical framework for the enablement of customers' participation in the open innovation process, with reference to the industrial preconditions; strategic preconditions; firms' innovation capacities; and integrative capacities.

Proposed analytical framework serves for deeper understanding on how firm facilitates the customer involvement and participation in OI process by creating the certain environment, conditions for enablement and what internal and external preconditions are inducing the customer enablement to participate in OI process. Based on created framework the further empirical analysis of customer enablement to participate in open innovation process may disclose the important success factors of the firm in open innovation by involving customers. The proposed analytical framework provides the basis for analysis of firm's behaviours and applied strategies regarding the enablement of customer's participation in the open innovation process.

\section{The enablement of customer participation in the open innovation process}

The studies of customer involvement in the new product development process (Von Hippel, 1978; Pinegar, 2000; Thomke and von Hippel, 2002; O'Hern and Rindfleisch A., 2008; Piller and Ihl, 2009), the user involvement in innovation process (Gales, Mansour-Cole, 1995; Rohracher 2005), customer partnering in the open innovation process (Reichwald and Piller, 2003), and customer as a source of innovation (Pinegar 2000, Piller and Ihl, 2009) discuss the types of knowledge inputs, roles and activities, interaction modes and competencies required along innovation process that would enable the cooperation with the customers. Thus, we might state that the enablement of customer participation in an open process is defined by the firm's activities, interaction modes and facilitating tools, but also firm's competencies as related to customer knowledge and interaction management at each stage of innovation.

In order to analyse the enablement of customer participation in an open innovation process, first we have to look at the innovation stages and the changing roles of the customer, that define the type of knowledge inputs, interaction modes and customer knowledge management and integration capabilities of the firm. Generally, innovation process incorporates three basic steps: first, idea collection and/or generation, development and specification (idea generation), second, value creation via transformation of ideas into prototypes and products (development), and third, product introduction into the market (commercialisation) (Vaisnore and Petraite, 2011). Further typologies derive from entire basic steps and vary according to the purposes of analysis and/or management decisions to be taken. For the purpose of our analysis, the Herstatt and Vervon (2007) five phase innovation process model is best suited, as it classifies innovation process by the typology of decisions to be taken within certain innovation development phase: 1) idea generation and evaluation, 2) concept development and product planning, 3) product development, 4) prototyping, piloting and testing, and 5) production, marketing and market entry. Each of the decision at certain stage requires various types of knowledge inputs from the customer, and thus the participation enablement mechanisms and required customer knowledge management capabilities of the firm would vary. The classification of customer knowledge inputs and customer enablement tools according to the innovation stages would also mean, that the firm might have sufficient capacities for customer enablement at one stage, but short in other stages, i.e. customer participation enablement in the open innovation process is neither smooth nor undisruptive process. Hereby Herstatt and Vervon (2007) distinguish first and second phase as the fuzzy front end innovation and argue, that early stages define and consequence the following innovation development steps up to the final stages. Herstatt and Lettl (2004) underline the importance of customer knowledge integration in the very beginning of R\&D activities. The customers' knowledge inputs supplement and help to ensure the applicability of future new products.

According to Bianchi, Cavaliere, Chiaroni, Frattini, Chiesa (2011), the early and later innovation phases differ by requirements concerning the level of risk, uncertainty and the need for new knowledge on the contrary to the existing one. In the open innovation case both- internal and external knowledge and innovation sources can be employed as required by the different phases of the innovation process. Customers are ones of the typical sources of innovation in the fuzzy front end phase (Herstatt and Vervon, 2007), where the risks and uncertainties are supposed to be at the highest level from the market perspective. Piller and Ihl (2009) highlight the role of customer in the back end innovation process: product design and testing. Piller and Ihl (2009) emphasize that in back end phases customer inputs have to be more concrete and elaborated in order to be valuable for firm. A higher degree of elaboration often requires a more structured approach for the interaction with customers than in the front end innovation stages. 
Piller and Ihl (2009) find that customers with lead user characteristics (by being ahead of main stream customers) provide important information about future trends and possible solution technologies, other customers as co'creators are more beneficial in the evaluation of innovative concepts or participation in the refinement of a prototype. Consequently, customers' contribution to open innovation process differs along with different phases of innovation process (Piller and Ihl (2009), and different roles (Reichwald and Piller (2003) customers may take during these different phases.

Customer's interaction in innovation process may vary from a passive object of observation and/or information provider to an active participant of the process (Fuller and Matzler, 2007). Depending on customers-firm interaction level customers can take a role from an idea generator, developer, tester and end user. The customers' role can define the customer-firm interaction activities. As shown in figure 1 these factors are interdependent.

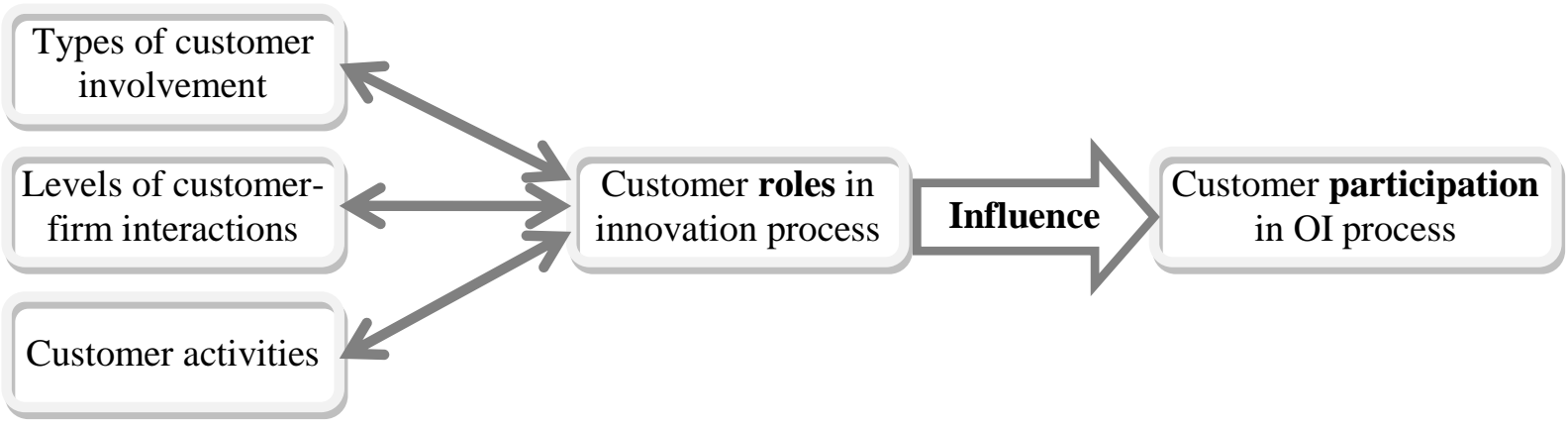

Figure 1. The influence on customer participation in OI process

The participation of customers in open innovation process is determined by the roles customers can take in respect of the type of involvement (Fuller and Matzler, 2007, Vaisnore and Petraite 2011).

Within the new product development context customer involvement by the Pinegar (2000) is defined as ,the interaction and/or collaboration between channel members (including customers and users) and company personnel during the course of product development to actualize a commercial product". According to Pinegar (2000) customer involvement in new product development can vary from simple information transfers in the form of suggestions or feedback to the firm, to the complex knowledge transactions where customers take an active role and contribute to the process intellectually, physically or financially. Thus new product development (NPD) is a part of innovation process it can be stated, that customer involvement in open innovation process generally requires the active customer participation.

Belkahla and Triki (2011) suggest that customer integration in innovation process is based on four key elements: object, stages, intensity and modes of integration. Herstatt and Lettl (2004) emphasizes that customer integration in the innovation process is determined by the activity level dimension (active/passive), the domain level dimension (user domain/technological domain) and the interaction between user and manufacturer dimension (create for, create with and create by users).

However the understanding on, how customer becomes able to be active and participate in open innovation (OI) process remains unclear. Subsequently, we combine the general definition of enabling ${ }^{1}$ as such and the context of customer participation in OI process and explain the user enablement as:

- firm's actions and created conditions to provide customers with the means or opportunity to participate in OI process,

- firm's actions and created conditions to make customer participation in OI possible, practical, or easy,

- firm's created the foundations for customers to operate,

- firm's given legal power, capacity, or sanction for customers to participate in OI.

Consequently from the analytical point of view in the frame of this paper the customer enablement to participate in open innovation (OI) process is assumed(defined??) as certain set of preconditions, tools and practices that the firm creates in order to facilitate the involvement of customers as external innovation

\footnotetext{
${ }^{1}$ http://www.merriam-webster.com
} 
partners. The internal and external factors which influence or even create the preconditions for customer enablement to participate in OI will be further analysed in the next part of the paper.

To sum up it can be stated, that open innovation is characterised as a sophisticated process that includes complex knowledge transactions among internal and external partners (Chesbrough, 2003). The OI process goes through main phases where the customer roles and the assigned tasks differ according to required knowledge inputs. Customer roles in open innovation process are impacted by different involvement and interaction types during diverse activities assigned to customer along the participation process. Customer participation enablement in the OI process requires the certain environment and facilitation as a background from firm and might be influenced by the variety of externally and internally defined factors which we define as the preconditions for the enablement of customer participation in the open innovation process.

\section{The preconditions for customer enablement to participate in the OI process}

The competencies and abilities in addition to motivation, stimulus and facilities for customer participation in innovation process can be affected by certain external and internal factors. These factors influence the customer enablement to participate in OI process by creating certain preconditions for it as demonstrated in figure 2. The background defined by existing preconditions might have an impact on the enablement of customer participation in OI process. In this part of the paper we combine the general definition of preconditions with the context of customer participation enablement and define it as existing conditions, circumstances, environments and settings that facilitate the customer participation in open innovation process and enables customer to be actively involved in it. We concentrate on the disclosure of in the scientific literature residing empirically evidenced factors that can set or/and impact the preconditions, and demonstrate these preconditions in more systematic way.

The number of past empirical studies on integrating customer into innovation process concentrated on the industrial goods and service fields (Herstatt and Von Hippel, 1992; Thomke and von Hippel 2002), and consumer goods (Franke and Piller, 2004, Hienerth, 2006, Fuller, Matzler, Hoppe, 2008; Luthje, Herstatt, and von Hippel 2005). There are also some evidences, that open innovation involving customers can be successful (with some challenges) in low-tech (Herstatt and Von Hippel, 1992) and high-tech industries, such as pharmaceuticals (Adelhelm, Braun, Reger, 2009; Bianchi, Cavaliere, Chiaroni, Frattini, Chiesa, 2011), consumer electronics (Christensen, Oleson, Kjær, 2005), sustainable energy technologies (Rohracher, 2005), medical equipment technology (Lettl, Herstatt, Gemuenden, 2006, Lettl 2007, Füller, Faullant, Matzler, 2010). Thus the customer integration levels and the tools along with techniques and facilities for user involvement differ in consistent with required knowledge inputs from customer.

However customer involvement in low-tech innovation (Herstatt and Von Hippel, 1992), where the necessity of very specific professional education and technology use practice is lower, might be more promising than in high-tech innovation process, where possibilities to enable customer to participate are limited due to higher technological complexity. This problem, according to Foss, Laursen, Pedersen (2011) is mostly related to the difficulties by transferring highly complex knowledge required in innovation process.

The customer integration should ensure the acquisition of sticky information (Von Hippel, 1994) which reflects customers' latent knowledge that is hard to transfer and capture. In the context of high technology based firms the more sophisticated mechanisms of knowledge transfer appeal for more active participation and moderation of the firm during the process (Kriaucioniene and Ragauskas, 2008, Vaisnore and Petraite - Kriaucioniene, 2009).

Depending on industry the product characteristics take effect on the customer enablement to participate in OI process additionally. Lin and Germain (2004) emphasize that 'product complexity refers to the degree of technology/engineering intensity and sophistication inherent in physical goods'. They propose a positive connection of product complexity with customer involvement in product development. In industries including complex products, product design and redesign tend to be more expensive and risky, therefore the user knowledge is essential for manufacturers and it opens the innovation process boundaries.

Consistent with Foss et. al. (2011) a complex product related knowledge that is transferred between a customer/user and a firm and is likely to require a significant interaction between the two parties. Though, when such knowledge is being transferred, the need for external knowledge sharing competencies is mostly important.

The evidences from the discussed previous studies reveal the importance of industry characteristics for the customer participation in OI. Industry characteristics take effect on firms' knowledge management, 
innovation strategies what evokes the preconditions for customer enablement to participate in OI process. In order to disclose the industry induced or industrial preconditions it is necessary analyse the sector characteristics, whether it is low-tech, medium-tech, or high-tech sector, product characteristics complex technology based or simple, and industry specifics. The preconditions relates to the type of customer competence needed to produce sophisticated knowledge and the variety of involvement methods throughout the innovation process.

On the basis of the most customer involvement in new product development studies are carried out in consumer goods sector, where customers remain end users and are playing most important role with their ideas for new products, and suggestions after product testing's. Though already Rosenberg (1982) revealed that the business clients can be actively involved in new product development disclosing that the airlines has an incentive to co-develop the airplane with the producer. Business clients benefit from solved individual problems during usage of developed technologies, manufactures benefit from advanced by new ideas, practical solutions.

Considering the innovation process, the enablement of end user participation is more likely possible on the idea generation, concept development phase due to mass production. End users are also capable to be testers at the commercialisation phase of innovation process. Business clients are more easily involved in innovation process particularly research and product development phase (Kahn and Pinegar, 1999). Although it depends on products - whether these appear to be the mass products or customised products.

Consequently firm aiming to facilitate the customer enablement to participate in open innovation process utilise different involvement tools as well as different knowledge management techniques. The customer profile defines the required settings for customer participation enablement.

Earlier studies show that open innovation is expected to be more successful for the large, multinational, technology companies, with big assets and wide range of customers (Chesbrough, 2003). Chesbrough et al. (2006) discuss that large firms differ from small firms in their adoption of open innovation. Firm size does influence the innovation strategy and value firms capturing ability on new technology (Vrande et al., 2009). Christensen et al. (2005) in the context of consumer electronics evidences that large, established companies and small start-ups manage open innovation differently, reflecting their variance place within the innovation system. Laursen and Salter (2006) argue that "there is a positive relationship between the human capital of a company and their degree of openness". Scholars state that the larger companies have more obtainable human resources to dedicate it for cooperation with external innovation partners. Therefore the larger companies are more likely to implement the open innovation strategies. Small firms often lack resources to develop and commercialize new product in-house and as a result are more often inclined to collaborate for innovation (Vrande et al. (2009). Consequently organisation size sets the preconditions for customer enablement in open innovation process.

Analysing the business model influence on customer enablement to participate in open innovation process the Chesbrough's (2006) Business model framework for innovation models (Undifferentiated; Differentiated; Segmented; Externally aware; Integrated; Adaptive) can be employed as it helps to identify how open the firms' business models currently are. Customer can be more active and has more possibility to interact with firm on the business models, where the main goals of the companies are related to acquisition of knowledge from various external sources. Analysis of the company's business model may reveal, how it reflects on firms' ability to engage external knowledge from customer for innovation process and how important that is for firm's success.

Company-customer interaction strategy reflects on firms' motivation and willingness to involve customers in innovation process. The modes of innovation refer to customers' participation enablement level. Piller and Ihl (2009) highlight three modes of customer participation in new product development: Mode 1 Design for customers: products are designed on behalf of customers; firms use customer information from diverse input channels to explore needs: listening into the customer domain by analysing sales data, internet $\log$ files, or surveying sales personnel; ethnography; quality function deployment; Mode 2 - Design with customers: display solutions or concepts to customers so they can react to proposed design solutions: pilot customers or beta users, concept testing, focus groups; output-driven innovation method; Mode 3 - Design by customers: there is an active integration of customer participation in NPD, often with tools that are either provided by the firm or by customers themselves. The manufacturer is either enabling its customers to codesign a solution or is implementing methodologies to efficiently transfer an innovative solution from the customer into the company domain. 
Either of the innovation models in the innovation process involves the general stages of idea generation, development and product commercialization. Each of the stages can be linked to different customer roles according to the modes of co-creation process, and therefore customer would take different activities in a value creation process. In the customer involvement and enablement context customer's interaction in innovation process may vary from a passive object of observation, information provider to an active participant of the process (Fuller and Matzler, 2007). Depending on customers, firm interaction level customers can take a role from an idea generator, developer, tester and end user. The customers' role can define the customer-firm interaction activities emphasised by Reichwald and Piller (2003).

Concequently, the customer participation in open innovation process is reliant on some strategic preconditions_that are defined by firm itself and influenced by customer characteristic (whether firm is operating in $\mathrm{B} 2 \mathrm{C}$ or $\mathrm{B} 2 \mathrm{~B}$ sector), organisation size (whether firm is using small company strategy or tended to grow, developing large multinational business), business model, and company-customer interaction strategy. The analysis of openness and external orientation in strategic perspective and its influence on external knowledge integration in open innovation process may reveal the preconditions for customer enablement to participate in the process.

Relating the firm's innovation capacities with the customer participation enablement, conditions for customer involvement differs along with novelty of innovation. Lettl (2007) states that user profiles appropriate for radical innovations differ significantly from those user types that are typically involved in incremental innovation. The differences are induced by the subject dimension of user involvement competence. While conventional marketing research techniques are appropriate for incremental innovations they are of limited value in radical innovation projects. Lettl (2007) empirically proves that radical innovation requires radically new ideas and solutions; these can be gained by identifying creative leading technology users consequently increasing creative capacity of an organization. Subsequently companies that work on radical innovations need to develop a completely different user involvement competence than companies that primarily generate incremental innovations. One of the key competences for radical innovation is the capability to identify and employ the highly creative users. Consequently the radicalness of innovation creates the preconditions for enablement of different creativity level users.

In relation to firms' strategy and the business model, the innovation strategy also takes effect on customer participation in innovation process. The level of openness defines the attraction and utilization of external knowledge during the process (Vaisnore and Petraite-Kriaucioniene 2009). The degree of customer involvement differs according to customer interaction type and strategic firm's innovation openness dimensions. While closed innovation is concentrated to use some information about customers as external players of innovation process, open innovation model integrates customer to the open innovation process for joint collaborative value creation (Reichwald and Piller, 2003).

According to Vanhaverbeke et al (2007), the openness of firm's innovation strategy is interrelated with the knowledge absorptive capacities. External knowledge can only be recognized; accessed and assimilated when firms develop new routines and adapt their organizational structure and culture to facilitate knowledge absorption. With reference to Chesbrough, Vanhaverbeke and West (2006) the utilization of more open strategies requires intense knowledge management practices and raise challenge to link external and internal knowledge sources within the open innovation boundaries.

Customer participation enablement in closed innovation relies on traditional market research tools, where customers are more passive targets for observation or information providers. In terms of open innovation strategy, the specific challenge is related on how to involve customers knowledge into the innovation processes at much more intense than traditional levels in order to achieve key benefits associated with open innovation model (Piller and Ihl, 2009).

The company's innovation strategy reflects to intellectual property management style whether it is defensive, restricted or open. It relates to the business model types defined by Chesbrough's (2006). In the cases of defensive and restricted intellectual property management strategy customer participation enablement remains limited. This again also depends on the industry and customer type, whether it is business client when company can have signed confidentiality contracts ant work together as a partner, or it is freely open to mas of customers for discussions and new suggestions.

In relation to organisation innovation strategy the organisational innovation culture takes effect on customer enablement to participate by creating innovations. In the context of open innovation practice Vrande et al. (2009) state that many barriers for innovation in firms are related to culture. The organisational culture reflects on firm's management style, communication among employees and customers, cooperation, 
networking, openness to external players, as well as affects knowledge absorption and sharing within and outside the firm's practice.

According to Belkahla and Triki (2011), the internal management capacity reveals the organizational culture and the values the firm wants to set up among its employees in order to effectively manage customer knowledge and foster innovation. Thus, it is not sufficient to integrate customers in the innovation process, effective management of the generated knowledge is also needed to succeed in new products development and launch. Internal management capability of the firm is largely reflected in knowledge sharing between employees, continuous learning from past experiences, the creativity promoting culture and communication effectiveness. For knowledge sharing, it reflects the employees' competence in disseminating and utilizing customer knowledge in order to enhance innovation through workshops, repeated interactions and informal exchanges of tacit and explicit knowledge between the staff members. For continuous learning, it is reflected in the ability of the firm to learn from previous experiences. For creativity promoting culture, it refers to the firm competence in infusing an organizational culture that supports and promotes creativity and innovativeness and finally, for effective communication internally (to its employees) and externally (to customers and other partners) all tasks related to new products.

Organizational practices may leverage the knowledge absorption from customers in the context of innovation. The practices that enhance communication and knowledge sharing leverage knowledge absorption and lead to higher innovative capacity (Foss et. all 2011). Users/customers often own "sticky" knowledge that is costly to transfer (von Hippel, 1998). Stickiness may be caused by various attributes of knowledge itself, such as the way it is encoded (in the form of tacit or codified knowledge), or it may be caused by the attributes of the agents seeking or providing knowledge (e.g., their cognitive capacity and motivation) (Foss et. all, 2011).

Consequently customer participation in open innovation process is dependent on firms' innovative capacities that are defined by innovation types (radical or incremental), innovation strategy (from closed to open), IP management strategy (from defensive to open), and organisational innovation culture. The analysis of innovation capacities in strategic perspective may reveal the preconditions for customer enablement to participate in innovation process with reference to knowledge management mechanisms.

Belkahla and Triki (2011) focuses on customer participation in innovation process from knowledge management perspective, and suggest, that customer knowledge driven innovation requires from the company a set of organizational competences and management skills as well as a mind-set of customer knowledge acquisition, dissemination, transformation and use for the sake of enhancing new products' performance.

The firm's integrative capacities of customer knowledge, according to Belkahla and Triki (2011), are defined as the capacities of the organization to involve customers in the innovation process in order to jointly create value. Integrative capacity of the firm is determined by the level of customer integration in the innovation process and the stage of customer integration. Integrative capacities impacts customer participation enablement by setting preconditions for knowledge management processes.

Witell, Kristensson, Gustafsson and Lofgren (2011) argues that an organizations collaborative competencies are the ones differ from perceiving the customer as a source of information, and to treating the customer as an active contributor with knowledge and skills. The latter has a positive effect on customer enablement to participate in open innovation process.

Open innovation can only be successful if the innovation partners have sufficient willingness to be involved and demonstrate the abilities and skills to participate. Piller and Ihl (2009) emphasise the necessary competences required by customers and firms to perform open innovation successfully. Three distinct competences of firm that enhance the success of open innovation with customers: disclosure competence, appropriation competence and integration competence. With regard to innovation process firms need: first, to disclose their problem in order to establish an interaction with innovative customers; second, to be able to capture and protect the knowledge co-produced with customers; third, to assimilate and integrate new knowledge co-produced with customers into their own innovation process.

Foss et.all (2011) stress that forms knowledge absorptive capacities refers not only to the acquisition or assimilation of information by an organization, but also to the organization's ability to exploit it and therefore, an organization's absorptive capacities does not simply depend on the organization's direct interface with the external environment. It also depends on transfers of knowledge across and within subunits. 
The internal processes and structure reveals the companies structural capacity of the organization to structure knowledge about, from and for customers and to classify it in data bases in order to transform it into easily sharable knowledge. In fact, IT software is needed for data processing and structuring. The Belkahla and Triki (2011) research evidences that some products have failed because there was no information safeguarding and follow up related to customer preferences, habits and attitudes towards these products.

The integrative capacity brings up to customer knowledge management, knowledge absorptive capacities, internal processes and structure, networking capabilities as well as technological infrastructure required for the firm in order to create the customer knowledge flows enabling settings. The preconditions influence the environment where customers can reveal their knowledge and incorporate it in to open innovation process.

Summarising all preconditions for enablement of customer participation in open innovation process it can be stated that these are interrelated. In most of the cases the preconditions influences some internal or external activities of the firm and facilitates the interaction with customer. Incorporating all disclosed preconditions we group them in four categories industrial settings, strategic settings, and, innovative capacities, integrative capacities and bring up the framework for analysis of preconditions that are affecting the enablement of customers participation in open innovation process from the firms perspective.

\section{Analytical framework for the enablement of customer's to participate in the OI processes}

Along with the review of scientific literature on customer (and user) participation, involvement, integration in innovation, open innovation process we analysed the residing preconditions which might enable customers participation in OI process. We have disclosed the preconditions which can create opportunities, means and foundations as well as give the legal power, capacity or make it easy and possible and facilitate customer participation in OI process.

Consequently preconditions for customer enablement to participate in open innovation process based on analysed scientific literature were summarised and grouped to industrial settings, strategic settings defined by the the firm and also innovation capacities and integrative capacities affected by the firm and customer together. The interdependent links among the enablement of customer participation in open innovation process and disclosed preconditions is presented in Figure 2.

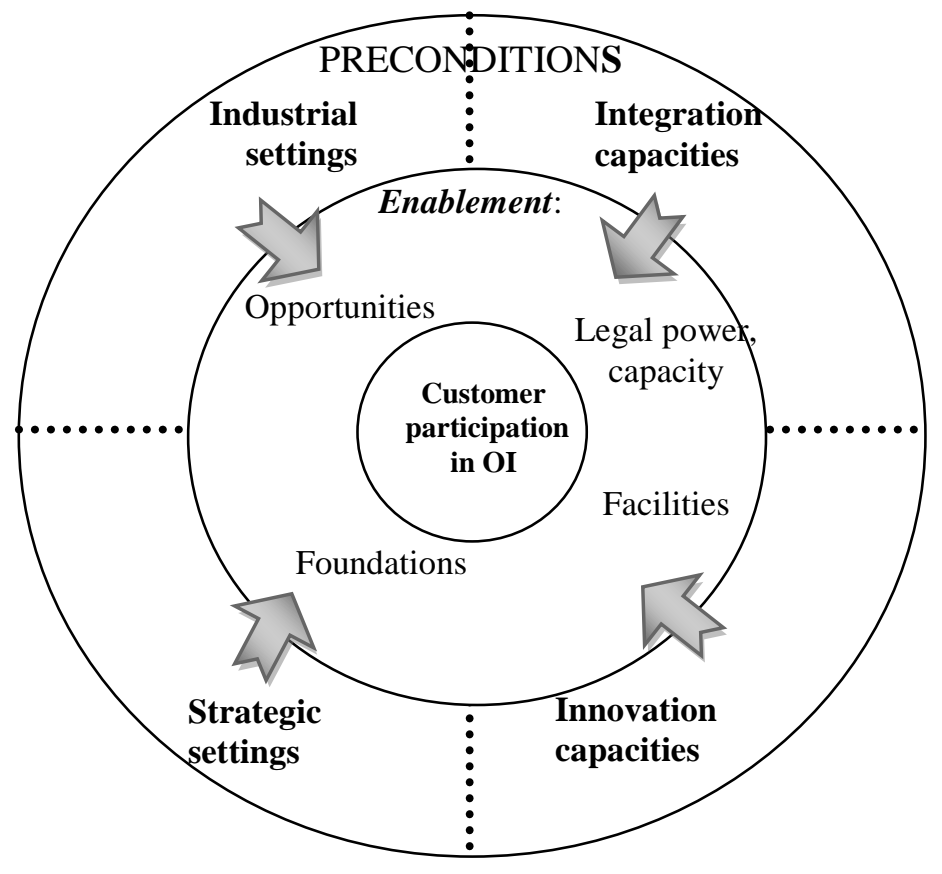

Figure 2. The links among the enablement of customer participation in OIP and main preconditions 
As discussed in previous chapters, the focal entity firm desires from customer is the knowledge required for innovation process in all possible means. The main groups of preconditions are important altogether in order to facilitate the enablement customer participation with the intention of enrich the innovation process with the knowledge acquired from customers. The given industrial and strategic settings within the firm can create positive or negative environment for enabling knowledge sharing, the innovative and integrative capacities provide the companies with the abilities to enable customers' knowledge acquisition and utilisation.

In order to disclose the particular preconditions that take effect on customer enablement to participate in OI process in each specific case, we propose a general analytical framework, which reveals the preconditions for customer enablement to participate in open innovation process as presented in Table 1.

The disclosed preconditions are inter-reliant. It influence or reflect on one another by creating specific settings for customer enablement. The sector and industry characteristics are defining the knowledge complexity and customer company interaction level during participation process. The technology intensity refers on customer knowledge management. The product characteristics reflects on customer characteristics by setting requirements for certain types of customers and relates to firm's innovation strategy. Firm's size might have effect on strategy as well as innovation strategy and knowledge management, it also reflects on technological infrastructure that is accessible for the customer involvement. Firm's business strategy relates to business mode, innovation strategy; business model relates to organisational culture, innovation strategy, and intellectual property management strategy. Firm-customer interaction strategy is affected by product complexity, industry characteristics customer knowledge management processes as well as firm's culture, networking capacities within the firm, and reflects on technological infrastructure in addition to involvement techniques for participation process. Firm's innovation strategy is also closely related to knowledge absorptive capacities and consequently customer knowledge management. Organisational culture and firm's internal processes and structures has influence on mostly al other preconditions.

To sum up we may assume that some factors are more open to be influenced by the business company like strategic settings and innovation as well as integrative capacities. Some others are more likely to be defined externally like industrial settings. Some preconditions (like industrial and strategic settings) are defined by the core business of the company and in the context of customer involvement are presumed as given; some others (innovation and integrative capacities) can be moderated and affected by the company more easily.

The framework should help to analyse the background for customer integration to OI process, and disclose what set of preconditions is facilitating the customer involvement and consequent the enablement of customer participation in open innovation process. The further analysis on how, firms are enabling customers to participate in open innovation process should be carried out based on the proposed framework.

Further research can be drawn to disclose the tools and techniques that companies employ to facilitate successful innovation process with customers the special attention drawing to customer enablement to participate in it. 
Table 1. Analytical Framework of the Enablement of Customer's Participation in the OI Processes

\begin{tabular}{|c|c|c|c|c|}
\hline \multicolumn{5}{|c|}{ PRECONDITIONS AND CHARACTERISTICS } \\
\hline \multirow{3}{*}{$\begin{array}{l}\text { INDUSTRIAL } \\
\text { PRECONDITIONS }\end{array}$} & Sector characteristics & $\begin{array}{l}\text { - Low-tech } \\
\text { - Medium-tech } \\
\text { - High-tech } \\
\end{array}$ & & \\
\hline & $\begin{array}{l}\text { Industry } \\
\text { characteristics }\end{array}$ & $\begin{array}{ll}\text { NAICS sectors: } & \text { - Energy } \\
\text { - Aerospace industry } & \text { - Enterta } \\
\text { - Agriculture industry } & \text { industry } \\
\text { - Chemical industry } & \text { - Food in } \\
\text { - Computer industry } & \text { - Health } \\
\text { - Construction industry } & \text { - Hospita } \\
\text { - Defence industry } & \text { - Inform } \\
\end{array}$ & $\begin{array}{l}\text { industry } \\
\text { inment } \\
\text { y } \\
\text { idustry } \\
\text { care industry } \\
\text { ality industry } \\
\text { ation industry }\end{array}$ & $\begin{array}{l}\text { - Insurance industry } \\
\text { - Manufacturing } \\
\text { - Mass media } \\
\text { - Telecommunications } \\
\text { industry } \\
\text { - Water industry }\end{array}$ \\
\hline & $\begin{array}{l}\text { Product } \\
\text { characteristics }\end{array}$ & $\begin{array}{l}\text { - End product } \\
\text { - Materials and particles } \\
\text { - Technologies } \\
\end{array}$ & $\begin{array}{l}\text { - Concepts/c } \\
\text { - Services }\end{array}$ & \\
\hline \multirow{6}{*}{$\begin{array}{c}\text { STRATEGIC } \\
\text { PRECONDITIONS }\end{array}$} & $\begin{array}{l}\text { Customer } \\
\text { characteristics }\end{array}$ & $\begin{array}{l}\text { - End user - B2C } \\
\text { - Business customers - B2B }\end{array}$ & & \\
\hline & Organisation size & $\begin{array}{l}\text { - Micro and Small companies } \\
\text { - Medium companies } \\
\text { - Large companies }\end{array}$ & & \\
\hline & Business strategy & $\begin{array}{l}\text { - Low-cost } \\
\text { - Differentiation } \\
\text { - Niche }\end{array}$ & & \\
\hline & Business model & $\begin{array}{l}\text { - Undifferentiated; } \\
\text { - Differentiated } \\
\text { - Segmented; }\end{array}$ & $\begin{array}{ll}\text { - } & \text { External } \\
\text { - } & \text { Integrate } \\
\text { - } & \text { Adaptiv }\end{array}$ & aware; \\
\hline & $\begin{array}{l}\text { Company-customer } \\
\text { interaction strategy }\end{array}$ & $\begin{array}{l}\text { - Design for customers } \\
\text { - Design with customers } \\
\text { - Design by customers }\end{array}$ & & \\
\hline & & $\begin{array}{l}\text { - Direct (hands on) } \\
\text { - Distance } \\
\text { - Virtual }\end{array}$ & & \\
\hline \multirow{4}{*}{$\begin{array}{l}\text { INNOVATION } \\
\text { CAPACITIES }\end{array}$} & Innovation type & $\begin{array}{l}\text { - Incremental/ Radical } \\
\text { - Sustaining/ Disruptive }\end{array}$ & & \\
\hline & Innovation strategy & $\begin{array}{l}\text { - Open } \\
\text { - Closed }\end{array}$ & $\begin{array}{l}\text { - Inside out } \\
\text { - Outside in }\end{array}$ & $\begin{array}{l}\text { owledge spin out), } \\
\text { nowledge spin in). }\end{array}$ \\
\hline & $\begin{array}{l}\text { Intellectual property } \\
\text { management }\end{array}$ & $\begin{array}{l}\text { - Defensive; } \\
\text { - Restricted; } \\
\text { - Open. }\end{array}$ & & \\
\hline & $\begin{array}{l}\text { Organisational } \\
\text { innovation culture }\end{array}$ & $\begin{array}{l}\text { - Creativity for new produc } \\
\text { development, } \\
\text { - Management and eldership; }\end{array}$ & $\begin{array}{r}\text { ct } \begin{array}{r}\text { Values } \\
\text { satisfa } \\
\text { custom }\end{array} \\
\end{array}$ & $\begin{array}{l}\text { related to customer } \\
\text { on (customer is important, } \\
\text { as innovation partner); }\end{array}$ \\
\hline \multirow{5}{*}{$\begin{array}{l}\text { INTEGRATIVE } \\
\text { CAPACITY }\end{array}$} & $\begin{array}{l}\text { Customer knowledge } \\
\text { management }\end{array}$ & $\begin{array}{l}\text { - Integration of explicit customer k } \\
\text { - Integration of tacit customer knov } \\
\text { - Integration of embedded custome }\end{array}$ & $\begin{array}{l}\text { nowledge; } \\
\text { wledge; } \\
\text { r knowledge. }\end{array}$ & \\
\hline & $\begin{array}{l}\text { Knowledge absorptive } \\
\text { capacities }\end{array}$ & $\begin{array}{l}\text { - Customer knowledge identifi- } \\
\text { cation and acknowledgement, } \\
\text { - Customer knowledge attraction; }\end{array}$ & $\begin{array}{r}\text { - Custome } \\
\text { and inte } \\
\text { - Custome } \\
\text { and expl }\end{array}$ & $\begin{array}{l}\text { knowledge assimilation } \\
\text { tion, } \\
\text { knowledge transformation } \\
\text { ation }\end{array}$ \\
\hline & $\begin{array}{l}\text { Internal processes and } \\
\text { structure }\end{array}$ & $\begin{array}{l}\text { - Employee creativity and deci- } \\
\text { sion making empowerment; } \\
\text { - Communication with custo- } \\
\text { mers processes; } \\
\text { - Cooperation with customers } \\
\text { processes; }\end{array}$ & $\begin{array}{l}\text { - Feedback } \\
\text { processes; } \\
\text { - Decision } \mathrm{r} \\
\text { - Structure } \\
\text { external k1 } \\
\text { - Agility, ag }\end{array}$ & $\begin{array}{l}\text { m customers systems and } \\
\text { king characteristics; } \\
\text { flection to openness and } \\
\text { wledge. } \\
\text { manufacturing }\end{array}$ \\
\hline & $\begin{array}{l}\text { Networking } \\
\text { capabilities }\end{array}$ & \multicolumn{3}{|c|}{$\begin{array}{l}\text { - Usage and integration level of user networks; } \\
\text { - Usage and integration level of communities of practice } \\
\text { - Usage and integration level of knowledge networks; } \\
\text { - Usage and integration level of social networks. }\end{array}$} \\
\hline & $\begin{array}{l}\text { Technological } \\
\text { infrastructure }\end{array}$ & \multicolumn{3}{|c|}{$\begin{array}{l}\text { - Internal communication and knowledge management systems; } \\
\text { - Customer knowledge management systems; } \\
\text { - Group work and creativity systems; } \\
\text { - Organizational environment in reflection to cooperation with customers }\end{array}$} \\
\hline
\end{tabular}




\section{Conclusions}

In conclusion the proposed analytical framework serves for the analysis of customer enablement to participate in the open innovation process. We combine the general definition of enabling as such and the context of customer participation in OI process and explain the user enablement as firm's actions and created conditions to: provide customers with the means or opportunity to participate in OI process, make customer participation in OI possible, practical, or easy; firm's created foundations for customers to operate and given legal power, capacity, or sanction for customers to participate in OI.

Consequently from the analytical point of view in the frame of this paper we describe the customer enablement to participate in OI process influenced by a certain set of preconditions that the firm creates or utilizes in order to facilitate the involvement of customers as external innovation partners.

We disclose that the main preconditions which create the settings for customer's enablement to participate in open innovation process are Industrial settings, strategic settings and innovation capacities as well as integrative capacities. Furthermore we highlight on necessity to analyse, how these preconditions are influencing the creation opportunities and facilities, provision of foundations and legal power as well as capacity for customers to participate in OI process.

The proposed analytical framework assists us to develop further research methodologies on the conditions that firms create or affect in order to enable their users to participate in open innovation process and benefit from it. The framework is complementing the scientific literature on the customer involvement in open innovation process by highlighting, how firm can facilitate the customer participation. The disclosed factors demonstrate the interdependence of main preconditions that are affecting the customer involvement. The factors might be creating the possibilities or obstacles for customers' enablement to participate in OI and cause its results. The analysis based on the proposed framework discloses the settings and facilities as the background that firms' provide for customer for participation in OI. Comparing with firm goals for innovation process the set of factors influencing the preconditions might disclose the success factors of innovation with customers in the context customer enablement to participate and benefit for the OI.

The proposed framework in further research can be utilised in order to analyse the enablement of customer's participation in the open innovation process with regard to the different tools, methods and techniques.

\section{References}

1. Adelhelm, S.; Braun, A.; Reger, G. (2009) Open Innovation and its applicability for pharmaceutical SMEs. Paper at ISPIM Conference - "The Future of Innovation" 2009, Vienna/Austria, 21-24 June 2009

2. Belkahla W., Triki A., (2011) "Customer knowledge enabled innovation capability: proposing a measurement scale", Journal of Knowledge Management, Vol. 15 Iss: 4, pp.648 - 674

3. Bianchi M., Cavaliere A., Chiaroni D., Frattini F., Chiesa V. Organisational modes for Open Innovation in the biopharmaceutical industry Technovation 31(2011)22-33

4. Chesbrough H. W. (2003). Open Innovation- The New Imperative for Creating and Profiting from Technology. Harvard Business School Press, 2003. 352 psl. ISBN 1578518377.

5. Chesbrough H., Vanhaverbeke W., West J. (2006) Open Innovation: Researching a New Paradigm. Oxford: Oxford University Press. ISBN: 0-19-929072-5

6. Chesbrough, H. W. (2007). Why companies should have open business models. Mit Sloan Management Review, 48(2), 22 .

7. Chesbrough, H., and Schwartz, K. (2007). Innovating business models with co-development partnerships. Research-Technology Management, 50(1), 55-59.

8. Christensen, J-F., Oleson, M.H., Kjær, J.S., 2005. The industrial dynamics of Open innovation - Evidence from the transformation of consumer electronics. Research Policy 34, 1533-1549.

9. Cohen, W. M., and Levinthal, D. A. (1990). Absorptive-Capacity - a New Perspective on Learning and Innovation. Administrative Science Quarterly, 35(1), 128-152.

10. Flatten, T. C., Engelen, A., Zahra, S. A., and Brettel, M. (2011). A measure of absorptive capacity: Scale development and validation. European Management Journal, 29(2), 98-116. doi: DOI 10.1016/j.emj.2010.11.002

11. Foss N. J., Laursen K., and Pedersen T. (2011) Linking Customer Interaction and Innovation: The Mediating Role of New Organizational Practices. Organization Science July/August 2011 22:980-999;

12. Franke, N., and Piller, F. (2004). Value creation by toolkits for user innovation and design: The case of the watch market. Journal of Product Innovation Management, 21(6), 401-415. 
13. Füller, Faullant, Matzler (2010) Triggers for virtual customer integration in the development of medical equipment - From a manufacturer and a user's perspective. Industrial Marketing Management 39 1376-1383

14. Fuller, J., and Matzler, K. (2007). Virtual product experience and customer participation - A chance for customercentred, really new products. Technovation, 27(6-7), 378-387. doi: DOI 10.1016/j.technovation.2006.09.005

15. Füller, Johann; Matzler, Kurt; Hoppe, Melanie (2008): Brand community members as a source of

16. Gales, L., Mansour-Cole, D., 1995. User involvement in innovation projects: toward an information processing model. Journal of Engineering and Technology Management 12, 77-109.

17. Gassmann O., Enkel E. (2004) Towards a Theory of Open Innovation: Three Core Process Archetypes

18. Herstatt C. and Vervon B. (2007) Management der frühen Innovationsphasen: Grundlagen, Methoden, neue Ansaetze. 2 Auflage. ISBN 978-3-8349-0375-4

19. Herstatt C., Lettl Ch. (2004) Management of "technology push" development projects. IJTM 27(2/3): 155-175

20. Herstatt, C., Von Hippel, E., 1992. From experience: Developing new product concepts via the lead user method: A case study in a "low tech" field. Journal of Product Innovation Management 9, 213-221.

21. Hienerth, Ch. (2006) "The commercialization of user innovations: the development of the rodeo kayak industry," R\&D Management, 36, 3 (June): 273-294

22. innovation. Journal of Product Innovation Management, 25 (6): 608-619.

23. Kaarela, I. (2010). Modes of Inbound Open Innovation in the Context of Dynamic Knowledge Creation. Proceedings of the 5th European Conference on Innovation and Entrepreneurship, 752-757

24. Kahn, K. B., and Pinegar, J. S. (1999). A typology of customer involvement in business-to-business commercialization. Annual CBIM / ISMB Atlanta Meeting, Atlanta, GA

25. Kriaucioniene, M.; Ragauskas, A. (2008) Transition via R\&D: emerging forms and strategies of corporate R\&D in the catch up countries (Lithuanian case). Globelics : 6th International Conference, 2008, 22-24 September, Mexico City. Mexico City : Globelics, 2008.

26. Lars Witell, Per Kristensson, Anders Gustafsson, Martin Löfgren, (2011) "Idea generation: customer co-creation versus traditional market research techniques", Journal of Service Management, Vol. 22 Iss: 2, pp.140 - 159

27. Laursen, K. and Salter, A. (2006). Open for innovation: The role of openness in explaining innovation performance among u.k. manufacturing firms. Strategic Management Journal, 27(2):131-150.

28. Lettl, C. (2007). User involvement competence for radical innovation. Journal of Engineering and Technology Management, 24(1-2), 53-75. doi: DOI 10.1016/j.jengtecman.2007.01.004

29. Lettl, Ch., Herstatt C. and Gemuenden H. G. (2006) "Users' contributions to radical innovation: evidence from four cases in the field of medical equipment technology," R\&D Management, 36, 3 (June): 251-272.

30. Lin and Germain (2004) Antecedents to Customer Involvement in Product Development: Comparing US and Chinese Firms. European Management Journal, 2004, vol. 22, issue 2, pages 244-255

31. Luthje, C., Herstatt, C., and von Hippel, E. (2005). User-innovators and 'local' information: The case of mountain biking. Research Policy, 34(6):951-965.

32. Matthew O’Hern and Aric Rindfleisch (2008) Customer Co - creation: A Typology and Research Agenda. Working Paper 4 - 2008. Innovation Thoughts on Innovation from the Wisconsin School of Business

33. Piller Frank. Ihl Christoph (2009). Open Innovation with Customers. Foundations, Competences and International Trends. Technology and Innovation Management Group. RWTH Aachen University. Germany

34. Piller, F., Ihl, C., and Steiner, F. (2010). Embedded Toolkits for User Co-Design: A Technology Acceptance Study of Product Adaptability in the Usage Stage. 43rd Hawaii International Conference on Systems Sciences Vols 1-5 (Hicss 2010), 164-173.

35. Pinegar J. S. (2000) Customer Involvement in Industrial Product Development: Creating Superior Products. April 25, available at http://www.pinegars.com/PDF_Files/Customer\%20Involvement\%20in\%20npd.pdf

36. Prahalad, C. K. (2004). The future of competition: Co-creating unique value with customers. Research-Technology Management, 47(3), 62-62.

37. Reichwald, R., \& Piller, F. T. (2003). From mass production towards customer integration and co-production. Wirtschaftsinformatik, 45(5), 515-519.

38. Rohracher H. (2005) User Involvement in Innovation Process. Strategies and Limitations from a Socio-Technical Perspective. Technik - und Wissenchaftaftsforshung Bd44. ISBN 3-89019-579-2

39. Rosenberg, N. 1982. Learning by using, Inside the Black Box: Technology and Economics. Cambridge: Cambridge University Press. 
40. Salter, A., and Laursen, K. (2006). Open for innovation: The role of openness in explaining innovation performance among UK manufacturing firms. Strategic Management Journal, 27(2), 131-150. doi: Doi 10.1002/Smj.507

41. Spithoven, A., Clarysse, B., and Knockaert, M. (2010). Building absorptive capacity to organise inbound open innovation in traditional industries. Technovation, 30(2), 130-141. doi: DOI 10.1016/j.technovation.2009.08.004

42. Steiner, F., Tarman, R. T., Ihl, J. C., and Piller, F. T. (2009). Learning from the Customer: Identifying Changing User Needs during Product Usage through Embedded Toolkits for User Innovation. Proceedings of Picmet 09 Technology Management in the Age of Fundamental Change, Vols 1-5, 696-706.

43. Thomke, S., and von Hippel, E. (2002). Customers as innovators - A new way to create value. Harvard Business Review, 80(4).

44. Vaisnore A., Petraite M. (2011) Customer Involvement into Open Innovation Processes: a Conceptual Model. Social sciences. Vol 73, No 3 p. 62-73 ISSN: 1392-0758

45. Vaisnore, A., and Petraite-Kriaucioniene, M. (2009). The Development of Open Innovation Model in Business: Concept Analysis and Limitations in a Case of Small Catching up Country. Changes in Social and Business Environment, 453-462.

46. Van de Vrande, V., de Jong, J. P. J., Vanhaverbeke, W., and de Rochemont, M. (2009). Open innovation in SMEs: Trends, motives and management challenges. Technovation, 29(6-7), 423-437. doi: DOI 10.1016/j.technovation.2008.10.001

47. Von Hippel E. (1978). Successful industrial products from customer ideas. Presentation of a new customer-active paradigm with evidence and implications. The Journal of Marketing. Vol. 42, No. 1, Jan., 1978 http://web.mit.edu/evhippel/www/papers/CAP-MAP\%201978\%20Jour\%20of\%20MKTG\%20evh.pdf

48. Von Hippel, E. (1994). "Sticky Information" and the Locus of Problem Solving: Implications for Innovation. Management Science, 40(4), 429-439.

49. von Hippel, E. (2007). Horizontal innovation networks - by and for users. Industrial and Corporate Change, 16(2), 293-315. doi: Doi 10.1093/Icc/Dtm005

50. Vonhippel, E. (1990). Predicting the Source of Commercially Valuable User Innovation Via Lead Users. Advances in Telecommunication Management, Vol 1, 1, 131-145.

51. Zahra, S. A., and George, G. (2002). Absorptive capacity: A review, reconceptualization, and extension. Academy of Management Review, 27(2), 185-203. 